\title{
GAYA STILISTIKA PUISI "PEREMPUAN SELALU INGAT" KARYA DIAN RENNUATI: KAJIAN KERELEVANSIAN DENGAN PEMBELAJARAN BAHASA INDONESIA DI SMA
}

\author{
Enny Hidajati \\ Dosen Universitas Bina Darma \\ Jalan Jenderal Ahmad Yani No.3 Palembang \\ Sur-el: enny.hidajati@binadarma.ac.id
}

Article info

Article history:

Received:14-02-2020

Revised :06-03-2020

Accepted:17-05-2020

\section{A B S T R A C T}

Dian Rennuati is a doctor and poet from Palembang. Dian is known to have a style of language (stylistic) which is very beautiful from the point of women. The poem under study entitled "Perempuan Selalu Ingat". The problem examined in this study is how the stylistic style of the poem "Perempuan Selalu Ingat" and the relevancies of poem "Perempuan Selalu Ingat" by Dian Rennuati as bahasa Indonesia teaching materials in high school. Therefore, this study aims to uncover the style of stylistics in the poem. This research is a type of library research using descriptive method. Based on research found five aspects of stylistics in poetry, namely diction, real words (concrete, denotative), images (images) majas (figuratively), rhythm and rhyme. Based on research that has been done, found the use of these five aspects. There is relevance poem as bahasa Indonesia learning materials in high school.

Keywords:

Poem, Stylistic,

Perempuan Selalu

Ingat, Dian Rennuati,

Learning.

Kata Kunci:

Puisi, Gaya Stilistika,

Perempuan Selalu

Ingat, Dian Rennuati,

Learning
Dian Rennuati seorang dokter sekaligus penyair yang berasal dari Palembang. Dian dikenal mempunyai gaya bahasa (stilistika) tersendiri yang sangat indah dari sudut perempuan. Puisi yang diteliti berjudul "Perempuan Selalu Ingat" Masalah yang dikaji dalam penelitian ini adalah bagaimana gaya stilistika puisi "Perempuan Selalu Ingat" dan bagaimana relevansi dengan bahan ajar bahasa Indonesia di SMA.. Oleh karena itu, penelitian ini bertujuan untuk mengungkap gaya stilistika dalam puisi tersebut dan relevansinya dengan pelajaran bahasa Indonesia di SMA. Penelitian ini berjenis penelitian perpustakaan dengan menggunakan metode dekriptif. Berdasarkan pelitian ditemukan 5 aspek stilistika dalam puisi, yaitu diksi, kata nyata( konkret, denotatif), imaji (citraan) majas (kiasan), ritme dan rima. Berdasarkan penelitian yang sudah dilakukakn, ditemukan pemakaian lima aspek ini. Kelima aspek tersebut dipergunakan secara efektif. Selain itu, ada relevansi dengan bahan ajar bahasa Indonesia di SMA.
Direktorat Riset dan Pengabdian Masyarakat Universitas Bina Darma. 


\section{JURNAL ILMIAH \\ BINA EDUKASI \\ ISSN 1979-8598 E-ISSN: 2655-8378 \\ http://journal.binadarma.ac.id/index.php/jurnalbinaedukasi \\ Vol. 13, No. 1, Juni 2020, $52-64$}

\section{PENDAHULUAN}

Semua orang pasti pernah mendengar, membaca, atau bahkan menulis puisi. Puisi merupakan karya sastra yang populer di Indonesia. Seringkali, puisi dianggap sebagai ungkapan perasaan pribadi penyair yang dituangkan dalam kata-kata yang indah dan terpilih. Puisi mengandung suatu hal penting yang akan diungkapkan sang penyair. Setiap puisi mengandung subject matter untuk dikemukakan atau ditonjolkan. Hal ini terntu saja tergantung kepada beberapa faktor, antar lain falsafah hidup, lingkungan, agama, pekerjaan, dan pendidikan sang penyair (Tarigan, 2015)

Bagi seorang Dian Rennuati, puisi ibarat dokumentasi berbagai peristiwa yang terjadi pada sebuah kurun waktu. Setiap tema dan diksi yang dipilih secara khusus akan mengabadikan ingatan tentang sesuatu. Demikian pula, buku kumpulan puisi Perempuan Selalu Ingat ini merupakan kumpulan memori yang lekat di ingatan (Rennuati, 2019). Sebagai seorang dokter, Dian Rennuati tidak melulu berkutat dengan dunia medis. Kepiawaiannya dalam menuangkan ide yang didapat dari aneka sumber tidak diragukan lagi. Ide-ide itu didapatkannya dari percakapan luring dan daring, berita koran, majalah, atau celotehan teman di media sosial (Rennuati, 2019).

Berawal dari ide-ide yang bertebaran dari berbagai sumber inilah, Dian Rennuati menuangkan pikiran dengan tema-tema keseharian dan bahasa keseharian. Tema dan bahasanya relatif sederhana namun kata-kata sangat bernas dan maknanya sangat dalam. Kata-kata sederhana yang dipilih merupakan kekuatan dari penyair yang saat ini bermukim di Palembang ini. Pemilihan kata sangat bagus dan menjadikan gaya tersendiri yang berbeda dengan penyair lainnya.

Dian Rennuati lahir dan dibesarkan di Palembang, 17 Desember 1979. Dia mulai menulis saat kuliah di Fakultas Kedokteran Universitas Sriwijaya. Dian dikenal sebagai salah satu inisiator terbentuknya Forum Lingkar Pena Sumatera Selatan tahun 2000. Awalnya, penyair ini menggeluti cerpen dan telah menerbikan beberapa antologi bersama teman-teman komunitasnya. Namun sekarang lebih memilih menuangkan gagasan dan imajinasinya dalam puisi. Beberapa karya puisinya bertebaran dalam beberapa antologi, seperti Kumpulan Puisi Kopi 1.550 mdpl (2016), Jejak Air Mata : dari Sttwe ke Kuala Langsa (2017), Epitaf Kota Hujan : Padang Panjang dan Puisi-Puisi Penyair Asia Tenggara (2018), Hati yang Mengeja (2018) dan Demure (2018).

Kumpulan puisi Perempuan Selalu Ingat diterbitkan pada Juni 2018 berisikan 106 puisi karya Dian Rennuati yang diproduksi dari tahun 2004-2018. Salah satu puisinya berjudul "Perempuan Selalu Ingat" (PSI) dijadikan sebagai judul buku kumpulan puisi ini. Sebagai seorang perempuan, Dian banyak menulis puisi bertemakan keperempuan, cinta, kasih sayang, romantisme, hujan, dan hal-hal keseharian di sekitar lingkungan dari sudut perempuan. Santoso 


\section{JURNAL ILMIAH \\ BINA EDUKASI \\ ISSN 1979-8598 E-ISSN: 2655-8378 \\ http://journal.binadarma.ac.id/index.php/jurnalbinaedukasi \\ Vol. 13, No. 1, Juni 2020, 52 - 64}

(2009) menyampaikan bahwa bagaimana kaum perempuan menggunakan bahasa untuk mengemukakan pandangannya adalah ladang yang menarik bagi pemahaman terhadap perempuan. Oleh karena itu, penelitian terhadap penggunaan gaya stilistika puisi ini amat menarik.

Peneliti sengaja memilih judul puisi "Perempuan Selalu Ingat" sebagai objek penelitian dengan beberapa pertimbangan, di antaranya puisi ini menjadi judul buku dan ikon, tentu memiliki keistimewaan bagi penulis. Selain itu, tema keperempuanan yang mendominasi kumpulan puisi ini, cukup terwakili dalam penelitian puisi ini.

Karya sastra, terutama puisi, mempunyai nilai keindahan tersendiri (Siswanto, 2013). Keindahan itu terbentuk melalui imajinasi yang dituangkan dalam kata-kata yang indah. Bisa jadi, kata-kata yang dipergunakan dalam mewakili perasaan ini adalah kata-kata biasa dalam kehidupan sehari-hari, namun telah melalui proses pemilihan, pertimbangan, pemilahan tertentu sehingga betul-betul dirasa efektif mewakili perasaan penyairnya. Tentu saja, penyair punya gaya tersendiri dalam menuangkan kreativitasnya itu. Menurut Ratna (2013), seorang penyair sejak semula sudah berpikir bahwa bahasa yang digunakan adalah bahasa puisi, bahasa dengan tingkat seleksi yang tinggi. Kata-kata yang terdapat di dalam puisi tidak semata-mata dipilih begitu saja. Kata-kata tersebut mengandung pengajaran kehidupan. Untuk memahaminya, perlu dianalisis secara mendalam.

Oleh karena itu, penelitian ini diharapkan dapat memberikan kontribusi dalam pembelajaran sastra terutama dalam bidang apresiasi puisi. Melalui penelitian stilistika, makna puisi dapat lebih mudah diungkap. Akhirnya, makna kehidupan yang disampaikan penyair dapat lebih mudah dipahami para pembacanya. Sehubungan dengan hal tersebut maka masalah yang diteliti adalah bagaimana gaya stilistika puisi "Perempuan Selalu Ingat" karya Dian Rennuati dan bagaimana relevansinya dengan pembelajaran bahasa Indonesia bagi siswa SMA. Ttujuan penelitian adalah untuk mengetahui gaya stilistika puisi "Perempuan Selalu Ingat" karya Dian Rennuati dan relevansinya dengan pembelajaran bahasa Indonesia bagi siswa SMA.

Penelitian tentang stilistika juga pernah dilakukan oleh beberapa orang, diantaranya (a) Tenti Yuliantini (2019) dengan judul "Kajian Stilistika terhadap Diksi dalam Kumpulan Puisi Malu (Aku) Jadi Orang Indonesia Karya Taufiq Ismail serta Pemanfaatannya sebagai Bahan Ajar Bahasa Indonesia di SMK" yang menunjukkan bahwa stilistika merupakan pisau kajian yang dapat digunakan untuk menemukan cara pengarang menggunakan diksi dalam mengungkapkan gagasannya melalui puisi. Penggunaan diksi dalam puisi Malu (Aku) Jadi Orang Indonesia didominasi kata konkret yang dapat membangkitkan imaji visual pembaca dengan memanfaatkan majas, ungkapan dan pengimajian. Hasil kajian dapat dimanfaatkan sebagai bahan ajar bahasa dan sastra Indonesia dalam bentuk modul di jenjang SMK; (b) Arinah Fransori (2017) dengan judul penelitian "Analisis Stilistika pada Puisi Kepada Peminta-Minta 


\section{JURNAL ILMIAH \\ BINA EDUKASI \\ ISSN 1979-8598 E-ISSN: 2655-8378 \\ http://journal.binadarma.ac.id/index.php/jurnalbinaedukasi \\ Vol. 13, No. 1, Juni 2020, 52 - 64}

Karya Chairil Anwar" yang menunjukkan bahwa Dalam kajian puisi tersebut, menonjolkan berbagai aspek pembentukan kata yang kuat dan tak terduga. Sikap Chairil Anwar yang kritis dalam menampilkan gambaran yang sesungguhnya tentang kehidupan rakyat miskin atau kaum melarat. Hal ini mampu menyampaikan pesan secara tidak langsung kepada pembaca, bagaimana sikap dan perilaku yang seharusnya dilakukan. Berdasarkan hasil analisis terhadap puisi Kepada Peminta-Minta karya Chairil Anwar yang menonjolkan berbagai aspek pembentukan kata yang kuat dan tak terduga. Kemudian dari aspek batin, bagaimana Chairil Anwar yang memiliki sikap ekspresionisme memberikan sajian puisi yang ekspresif. Puisi ini juga menunjukkan sikap sosial dan kenyataan yang terjadi pada masyarakat; (c) Penelitian dengan judul "Kajian Stilistika pada Puisi-Puisi Chairil Anwar Sebagai Sarana Pebelajaran Apresiasi Sastra" dilakukan oleh Nyoto Harjono (2012) mendeskripsikan bahwa kajian stilistika pada puisi bertujuan untuk mempermudah pemahaman makna puisi. Ketiga penelitian tersebut berfokus pada kajian stilistika dengan objek peneltian berupa puisi-puisi Indonesia karya penyair ternama.

\section{METODOLOGI PENELITIAN}

\subsection{Puisi}

Puisi dalam KBBI berarti ragam sastra yang bahasanya terikat oleh irama, matra, rima, serta penyusunan larik dan bait. Namun, Luxemburg (1992) menyampaikan bahwa puisi itu merupakan teks-teks monolog yang berisi bukan bukan pertama-tama meupakan sebuah alur. Artinya, isi puisi bukanlah semata-mata sebuah cerita tetapi lebih merupakan ungkapan perasaan pengatang. Sementara itu, Waluyo (dalam Siswanto, 2013) menyampaikan bahwa puisi adalah bentuk karya sastra yang mengungkapkan pikiran dan perasaan penyair secara imajinatif dan disusun dengan mengonsentrasikan struktur fisik dan struktur batinnya. Siswanto (2013) menyampaikan bahwa puisi merupakan karya yang dimaksudkan oleh pengarang sebagai puisi dan diterima dengan sama oleh pembaca.

\subsection{Gaya Stilistika}

Gaya bahasa dalam kaitannya dengan pemilihan kata-kata ini sering disebut dengan stilistika. Stilistika (stylistic) yaitu ilmu tentang gaya. Istilah lain di antaranya, gaya bahasa, ragam bahasa, estetika bahasa, Menurut Shipley (dalam Ratna, 2013:8), stilistika adalah ilmu tentang gaya (style), sedangkan style itu sendiri berasal dari akar kata stilus (Latin). Stilus semula berarti alat berujung runcing yang dipergunakan untuk menulis di atas bidang berlapis lilin. Benda runcing ini berkonotasi bermacam-macam, di ataranya, menusuk, menggores, melukai menembus. Pada dasarnya, disinilah letak makna kata stilus sehingga kemudian berarti gaya bahasa sekaligus berfungsi sebagai penggunaan bahasa yang khas. 


\section{JURNAL ILMIAH \\ BINA EDUKASI \\ ISSN 1979-8598 E-ISSN: 2655-8378 \\ http://journal.binadarma.ac.id/index.php/jurnalbinaedukasi \\ Vol. 13, No. 1, Juni 2020, 52 - 64}

Dalam bidang bahasa, stylus berarti cara-cara penggunaan bahasa yang khas sehingga menimbulkan efek tertentu. Sedangkan menurut Ratna (2013), stilistika sebagai bagian dari ilmu sastra dan disempitkan sebagai ilmu gaya bahasa dalam kaitannya dengan aspek-aspek keindahan. Gaya bahasa pun harus dipahami sebagai entitas yang telah memiliki hakikat tersendiri.

Pada umumnya, kreativitas dan imajinasi, sistem konvensi, dan hubungannya dengan struktur sosikultural secara keseluruhan dianggap sebagai ciri-ciri utama dalam rangka membedakan antara puitika bahasa dan sastra. Analisis stilistika dengan demikian adalah analisis bahasa itu sendiri dengan mempertimbangkan keterkaitannya dengan konvensi sastra dan budaya (Ratna, 2013). Al Ma'ruf (2009) mengemukakan bahwa style 'gaya bahasa' adalah cara mengungkapkan gagasan dan perasaan dengan bahasa khas sesuai dengan kreativitas, kepribadian, dan karakter pengarang untuk mencapai efek tertentu, yakni efek estetik atau efek kepuitisan dan efek penciptaan makna. Gaya bahasa dalam karya sastra berhubungan erat dengan ideologi dan latar sosiokultural pengarangnya. Dengan demikian dapat disimpulkan bahwa gaya bahasa atau stilistika berkaitan dengan aspek keindahan. Proses penciptaan itu sendiri dilakukan secara sadar oleh penyairnya dan menjadi ciri khas tertentu sang penyair.

\subsection{Metode Penelitian}

Berkaitan dengan stilistika, penelitian puisi "Perempuan Selalu Ingat" ini menggunakan penelitian perpustakaan (library research). Menurut Semi (2012), penelitian perpustakaan yaitu penelitian yang dilakukan di kamar kerja peneliti atau di ruang perpustakaan dimana peneliti memperoleh data dan inforamasi tentang obyek penelitiannya lewat buku-buku atau alat-alat audio visual lainya . Sedangkan metode kerja pada penelitian ini menggunakan metode kualitatif yaitu mengutamakan kedalaman penghayatan terhadap interaksi antar konsep yang dikaji secara empiris.

Teknik pengumpulan data yang digunakan adalah teknik dokumentasi. Data penelitian adalah puisi "Perempuan Selalu Ingat" karya Dian Rennuati. Data dianalisis menggunakan teori Morris dalam Tarigan (2015). Morris membagi metode puisi menjadi lima, yaitu (1) diksi, (2) imaji, (3) kata nyata, (4) majas, (5) ritme dan ritma dengan penjelasan sebagai berikut.

\subsubsection{Diksi.}

Diksi berarti pilihan kata yaitu daya pikir untuk membayangkan atau menciptakan gambar kejadian berdasarkan kenyataan atau pengalaman seseorang. Dalam puisi, pilihan kata sangat penting mengingat dalam hal ini dapat mencerminkan ruang, waktu, falsafah, amanah, efek, dan nada puisi dengan tepat. Pemilihan kata tersebut dapat berupa kata-kata denotatif maupun katakata konotatif. Kata denotatif berarti kata yang memiliki makna sebenarnya, sedangkan kata konotatif berarti kata kiasan. 


\section{JURNAL ILMIAH}

BINA EDUKASI

ISSN 1979-8598 E-ISSN: 2655-8378

http://journal.binadarma.ac.id/index.php/jurnalbinaedukasi

Vol. 13, No. 1, Juni 2020, 52 - 64

\subsubsection{Imaji}

Imaji adalah daya bayang, biasa disebut juga dengan citraan. Dalam puisi , imaji bertujuan untuk membawa pembaca agar dapat merasakan apa yang dirasakan penyair yang telah dituangkan dalam sebuah puisi. Penyair harus pandai memilih kata-kata yang tepat untuk memperkuat daya bayang pikiran pembaca.

\subsubsection{Kata Nyata}

Kata nyata adalah kata yang konkret dan khusus, bukan kata yang abstrak atau kata yang bersifat umum. Pemilihan kata nyata sangat membantu penyair menyampaikan tujuan puisinya. Puisi tentang amarah akan lebih kongkret dan bisa membawa pembaca merasakan apa yang diinginkan oleh penyair jika pemilihan kata nyatanya kuat, contohnya dalam kata membuncah, amarah, bedebah, benci, dan lain sebagainya.

\subsubsection{Majas}

Majas adalah kata kiasan. Penyair akan lebih mudah menjelaskan sesuatu kepada pembaca dengan majas persamaan, perbandingan, maupun kata-kaya kias lainnya. Kiasan juga menjelaskan hal-hal yang bersifat abstrak menjadi konkret.

\subsubsection{Ritme dan Rima}

Ritme adalah irama, yaitu turun naiknya suara secara teratur. Sedangkan rima atau sajak adalah pengulangan bunyi yang berselang, baik di dalam lirik sajak, maupun pada akhir larik sajak yang berdekatan. Ritme dan rima sebuah puisi erat sekali hubungannya dengan rasa, suara, dan makna. Beberapa jenis rima antara lain menurut posisinya yaitu rima awal dan rima akhir. Menurut susunannya rima juga dibagi menjadi rima berangkai, rima berselang, rima berpeluk.

\section{HASIL DAN PEMBAHASAN}

\subsection{Puisi "Perempuan Selalu Ingat"}

\section{Perempuan Selalu Ingat}

Bersuluh bulan, didekapinya mimpi

Ada yang diam-diam melingkari

Berluruhan madah di setiap jejak; menguasai

Hati rentan puji kini diuji

Oleng bermandi buncah menlingkungi

Inilah semabuk-mabuk puisi

Tiap kali rindu menusuk ubun,

Dihembusnya kalimat hingga naik kelapis langit, Mengetuk-ngetuk pintu Yang Tunggal

Dalam lindap malam 


\section{JURNAL ILMIAH}

BINA EDUKASI

ISSN 1979-8598 E-ISSN: 2655-8378

http://journal.binadarma.ac.id/index.php/jurnalbinaedukasi

Vol. 13, No. 1, Juni 2020, 52 - 64

Diperasnya habis air mata hingga gersang

Mencukil pasrah, di haribaan-Nya berserah

Itulah setulus-tulus puisi

Perempuan ini, mengingat setiap detil persembahan

Helai cakap, aduan, dan sedu sedan

Kemana mencari perubahan akan gundah

Yang bersarang geming. Tiada layak anutan selain nabi

Mesti dicari iktibar dalam peri. Itulah sebenar-benar puisi

Menyepi sendiri ia, dalam merdu desir nadi

Tak boleh seorang tahu akan palungnya kalbu

Sungguh, rahasia, adalah sepuisinya puisi

Ah, sebab perempuan selalu ingat,

Jangan gegabah ukir namamu di jantungnya

Kan jelma laksa sembilu jika kau abai dan berlalu

(Febuari, 2018)

Dalam puisi "Perempuan Selalu Ingat" karya Dian Rennuati dianalisis dengan analisis stilistika sebagaimana yang dikemukakan oleh Henry Guntur Tarigan. Untuk memudahkan analisis akan dilakukan per bait. Penelitian stilistika mempunyai dua tujuan, yaitu meneliti gaya bahasa kemudian dari gaya bahasa itu dilanjutkan dengan meneliti fungsinya sebagai pembangun makna dalam karya sastra. Dalam penelitian ini diteliti terlebih dahulu gaya bahasa puisi yang kemudian diteliti fungsi gaya tersebut dalam pembentukan makna.

\subsection{Bait I}

Bersuluh bulan, didekapinya mimpi

Ada yang diam-diam melingkari

Berluruhan madah di setiap jejak; menguasai

Hati rentan puji kini diuji

Oleng bermandi buncah melingkungi

Inilah semabuk-mabuk puisi

Bersuluh berarti menggunakan suluh. Dalam KBBI, "suluh" bermakna barang yang dipakai untuk menerangi (biasa dibuat dari daun kelapa yang kering); obor. Bersuluh bulan bermakna menggunakan sinar bulan sebagai suluh, penerang. Pada masa dulu, sinar bulan amat bermanfaat untuk menerangi malam hari. Saat ini, di beberapa daerah yang belum dialiri listrik, sinar bulan juga masih sangat diandalkan. Pemilihan kata "suluh" dirasa tepat dibadingkan sinonimnya, yaitu 'obor'. Suluh dirasa lebih tenang, tidak terlalu berkobar apinya dan terasa cocok 


\section{JURNAL ILMIAH \\ BINA EDUKASI \\ ISSN 1979-8598 E-ISSN: 2655-8378 \\ http://journal.binadarma.ac.id/index.php/jurnalbinaedukasi \\ Vol. 13, No. 1, Juni 2020, 52 - 64}

disandingkan dengan kata "bulan" yang dirasa lebih lembut sinarnya dibandingkan dengan matahari.

Didekapinya mimpi menggambarkan citraan gerak yaitu mimpi seolah kawan akrab, kesayangan, sesuatu yang amat berharga sehingga didekap dengan erat. "Dekap" terasa lebih hangat dari sekedar pelukan karena menggambarkan kemesraan dan kasih sayang. Selain itu, penggunaan majas personifikasi dalam penggalan kalimat di atas, mampu memberikan gambaran seolah mimpi adalah makhluk hidup yang dapat didekap dengan mesra.

Diam-diam melingkari bermakna membuat lingkaran. Dilingkari bermakna menyeluruh, lengkap, sehingga pilihan kata (diksi) ini amat tepat menggambarkan perasaan yang memenuhi seluruh diri.

Berluruhan madah diambil penyair untuk menggambarkan pujian yang banyak disampaikan. Kata "berluruhan" bermakna berjatuhan sengaja dipilih karena mewakili kondisi jatuh namun sangat elegan, layaknya salju yang jatuh dengan lembut. Penggunaan kata "madah" jarang dijumpai dan penyair memilih kata ini untuk memberikan kesan mendalam serta membangkitkan rasa ingin tahu pembaca.

Hati rentan puji kini duji menimbulkan ritme dan rima yang indah menggambarkan suasana hati manusia yang secara fitrah suka akan pujian, namun terselip sebuah peringatan akan pujian yang bisa jadi bumerang ujian bagi yang kurang berhati-hati.

Oleng bermandi buncah melingkungi sebuah kalimat yang mengedepankan citraan gerak seakan pembaca turut bergerak seperti perahu yang oleng oleh deburan ombak.

Dalam KBBI, “oleng” adalah situasi berayun-ayun ke kiri ke kanan (tentang perahu dan sebagainya); bergoyang-goyang. Sementara itu, "buncah” berarti gelisah, kacau. Paduan kata "oleng" dan "buncah" ini terlihat konkret untuk menggambarkan situasi yang tidak nyaman dan sulit.

Bait pertama ditutup dengan kalimat inilah semabuk-mabuk puisi. "Mabuk" dapat bermakna denotatif yaitu situasi tidak sadar, pening karena pengaruh minuman keras. "Mabuk" bisa juga situasi badan yang tidak nyaman karena perjalanan, seperti mabuk darat atau mabuk laut. Namun dalam kalimat ini, "mabuk" juga bermakna konotasi yaitu 'tergila-gila', 'sangat berahi'. Penyair menggambarkan situasi mabuk karena perahu yang oleng dan situasi kacau sehingga membuat suasana tidak nyaman. Selain itu, penyair juga menggambarkan situasi mabuk seseorang akan pujian yang membuat diri tergila-gila dan sangat berhasrat pada seseorang.

Bait pertama ini sangat menonjol rima akhir yang diakhiri dengan huruf vokal $[i]$ yang mewakili rasa bahagia, ringan, dan ceria. Rima ini terinspirasi dari bentuk syair yang mempunyai sajak sama tiap akhir kalimat. 


\subsection{Bait II}

Tiap kali rindu menusuk ubun,

Dihembusnya kalimat hingga naik kelapis langit,

Mengetuk-ngetuk pintu Yang Tunggal

Dalam lindap malam

Diperasnya habis air mata hingga gersang

Mencukil pasrah, di haribaan-Nya berserah

Itulah setulus-tulus puisi

Kalimat tiap kali rindu menusuk ubun terasa sangat unik. "Rindu" biasanya dilekatkan pada perasaan, seperti halnya marah, sedih, sayang, dan yang lainnya. Namun dalam kalimat ini, "rindu" dikaitkan dengan "ubun", bagian yang empuk dari kepala dekat dahi atau bagian puncak kepala. Diksi ini dipakai untuk menggambarkan rasa rindu yang sudah sedemikian dalam sehingga mengganggu pikiran.

Dihembusnya kalimat hingga naik kelapis langit, Mengetuk-ngetuk pintu Yang Tunggal bermakna doa yang disampaikan kepada Tuhan Yang Maha Tunggal. Pemakaian kata "dihembusnya" membuat citraan perabaan, pembaca seolah merasakan hembusan angin, pelan meski tidak terlihat namun data dirasakan di permukaan kulit.

"Mengetuk-ngetuk" membangkitkan citraan pendengaran seakan-akan pembaca diajak untuk mendengarkan suara ketukan pintu, mohon dibuka oleh sang tuan rumah. Dalam hal ini, doa dilantunkan diam-diam untuk memohon pertolongan Sang Kuasa.

Mencukil pasrah merupakan diksi yang bagus untuk menyampaikan bahwa keikhlasan itu terkadang harus dipaksakan. "Mencukil" bermakna mengambil sesuatu yang kecil dengan usaha tersendiri. Oleh karena itu, perlu upaya agar sampai pada suasana kepasrahan atas semua ketetapan-Nya.

Setulus-tulus puisi adalah metafora, pembanding kondisi batin seseorang yang mengadu apa adanya kepada Tuhannya sebagaimana puisi yang tulus dan apa adanya mengungkapkan perasaan sang penyair.

Dalam bait ini dipergunakan banyak kosakata yang dipilih secara cermat oleh penyair. Pemilihan kata (diksi) tersebut dipergunakan untuk mendapatkan kebaruan makna, mengungkap kembali mkna lama yang sudah jarang dipakai dan untuk mencari perhatian pembaca. 


\section{JURNAL ILMIAH \\ BINA EDUKASI \\ ISSN 1979-8598 E-ISSN: 2655-8378 \\ http://journal.binadarma.ac.id/index.php/jurnalbinaedukasi \\ Vol. 13, No. 1, Juni 2020, 52 - 64}

\subsection{Bait III}

Perempuan ini, mengingat setiap detil persembahan

Helai cakap, aduan, dan sedu sedan

Kemana mencari perubahan akan gundah

Yang bersarang geming. Tiada layak anutan selain nabi

Mesti dicari iktibar dalam peri. Itulah sebenar-benar puisi

Pada kalimat helai cakap, aduan, dan sedu sedan, menggambarkan percakapan batin, pengaduan atasa segala keresahan dan sedu sedan tangisan kesedihan. Satuan yang dipergunakan adalah "helai" yang sengaja dipilih untuk menggambarkan sesuatu yang banyak, tipis, ringan, berguguran layaknya dedaunan. Oleh karena itu, diksi yang dipilih dirasa amat tepat.

Mesti dicari iktibar dalam peri. Itulah sebenar-benar puisi bermakna harus mencari pelajaran dan hikmah dalam setiap kejadian. Begitu pula dengan puisi yang memberikan pengajaran dari makna-makna yang dikandungnya.

Dalam bait ini, penyair mengungkapkan salah satu karakter perempuan yaitu, teliti, cermat, dan mampu mengingat hal-hal detil dan kecil. Namun, dengan segala keresahan di hati, si penyair ingin meyampaikan bahwa seseorang harus tetap berlaku sesuai tuntunan ajaran agama agar tidak keliru dalam melangkah.Setiap peristiwa dan ujian pasti ada hikmah untuk manusia.

\subsection{Bait IV}

Menyepi sendiri ia, dalam merdu desir nadi

Tak boleh seorang tahu akan palungnya kalbu

Sungguh, rahasia, adalah sepuisinya puisi

Pada penggalan kalimat dalam merdu desir nadi digunakan citraan pendengaran untuk menggambarkan aliran nadi dengan dengan kemerduan suara. Irama yang tetap dalam aliran darah seakan hanya bisa dirasakan dan didengarkan oleh seseorang yang menyepi sendiri.

Palungnya kalbu menggunakan majas metafora untuk menggambarkan kedalaman perasaan hati manusia yang tidak dapat diketahui siapa pun kecuali sang pemiliknya. "Palung" dalam KBBI berarti bagian laut yang terdalam, bentuknya seperti jurang memanjang dengan tebing yang terjal.

Kedalaman isi perasaan hati manusia itu sama halnya dengan puisi. Puisi merupakan sarana penyair untuk meyampaikan perasaannya. Terkadang, penyair mengungkapkan hal-hal tidak secara langsung namun dalam bentuk kata-kata yang menyembunyikan makna sebenarnya. Hal ini tergambar dalam kalimat sungguh, rahasia, adalah sepuisinya puisi. 


\section{JURNAL ILMIAH \\ BINA EDUKASI \\ ISSN 1979-8598 E-ISSN: 2655-8378 \\ http://journal.binadarma.ac.id/index.php/jurnalbinaedukasi \\ Vol. 13, No. 1, Juni 2020, 52 - 64}

\subsection{Bait V}

Ah, sebab perempuan selalu ingat,

Jangan gegabah ukir namamu di jantungnya

Kan jelma laksa sembilu jika kau abai dan berlalu

Bait ini menjadi sangat kunci karena memuat inti dari tema puisi ini. Perempuan mempunyai daya ingat yang sangat tajam. Hal ini sesuai degan karakteristik yang disampaikan oleh Kartono ( 2006) bahwa sifat-sifat wanita yaitu lebih bersikap memelihara, melindungi, lebih menetap, dan mengawetkan (konservasi). Inilah yang menjadi bukti kekuatan wanita yang sangat hebat dan dahsyat namun kadang-kadang bisa menjadi tragedi kehidupannya.

Perempuan punya daya ingat yang kuat. Oleh karena itu, sebuah sindiran ditujukan pada kaum lelaki agar tidak gampang memberikan harapan. Harapan itu akan diukir dalam hati sang perempuan. Awalnya akan memberi harapan namun berubah menjadi sembilu yang amat pedih.

Laksa sembilu adalah kulit buluh yang tajam seperti pisau untuk menyayat daging. Laksa adalah kata yang bermakna sepuluh ribu. Dengan demikian. Laksa sembilu bermakna rasa sakit dan perih yang teramat pedih sepuluh ribu kali pedihnya. Tentu saja, yang dimaksud adalah rasa pedih dan sakit yang luar biasa karena kekecewaan yang luar biasa. Pemakaian "sembilu" membangkitkan citraan peraba seolah kita ikut merasakan perihnya daging yang tersayat. Badan merasakan pedih yang sangat mendalam.

\subsection{Relevansi Puisi "Perempuan Selalu Ingat" karya Dian Rennuati sebagai Bahan Ajar Bahasa Indonesia}

Kurikulum 2013 menyarankan agar mempergunakan pendekatan ilmiah dalam sebuah proses pembelajaran. Dengan demikian, hasil pembelajaran diharapkan lebih melekat karena siswa melakukannya dengan prosedur berbasis fakta. Pembelajaran berbasis pendekatan ilmiah dimulai dari mengamati, menanya, mengolah, menyajikan, menyimpulkan, sampai mencipta. Selain itu, proses ini akan menumbuhkan rasa ingin tahu, mendorong observasi dan analisis, serta komunikasi.

Pada dasarnya, pembelajaran sastra dalam Bahasa Indonesia khususnya sastra merupakan salah satu pembelajaran yang membuat siswa lebih kooperatif dan interaktif, karena sastra merupakan sebuah pengalaman. Puisi "Perempuan Selalu Ingat" sendiri merupakan puisi yang menggambarkan ketegaran, keikhlasan, semangat, seorang perempuan dalam menghadapi kehidupan. Puisi ini memberikan pelajaran empati, rasa tanggung jawab terhadap perbuatan, dan kepasrahan total kepada Tuhan selaku insan beriman. Dengan demikian, banyak nilai moral yang dapat dipetik agar para siswa dapat meresapi seluruh pesan moral yang terkandung di dalamnya. 


\section{SIMPULAN}

Dari uraian dan pembahasan puisi "Perempuan Selalu Ingat" dapat disimpulkan bahwa penggunaan diksi, imaji, kata nyata, majas, ritme, dan ritma digunakan secara baik oleh penyair. Penggunan diksi sangat efektif dengan memilih secara khusus katakata yang mewakili perasaan dan suasana hati penyair. Kata-kata yang dipilih itu seperti suluh, obor, berluruhan, madah, buncah, oleng, mengetuk, gersang, mencukil, geming, iktibar, palung, laksa, sembilu. Penyair memilih kata-kata tersebut dengan berbagai pertimbangan. Kata-kata tersebut dipilih dengan maksud untuk menarik perhatian, membangkitkan kembali kosa kata lama, dan menggambarakan kedalaman makna.

Selain itu, penyair banyak menggunakan imaji atau citraan. Penyair menggunakan berbagai jenis citraan untuk memberikan gambaran lebih kuat pada pembaca. Citraan gerak, suara, pendengaran, peraba, dipergunakan dalam puisi ini. Contoh penggunaan citraan pada didekapinya mimpi menggambarkan citraan gerak. Selain itu, citraan pendengaran pada kalimat mengetuk-ngetuk, citraan perabaan pada dihembuskannya.

Kata-kata nyata, konkret dan khusus dipergunakan untuk mewakili perasaan sedih, syahdu, kecewa, dan kegalauan. Kata-kata seperti, hati, puji, rindu, air mata, pasrah, sedu sedan, gundah, menyepi, rahasia secara nyata mewakili ungkapan pesan puisi ini.

Majas atau perbandingan dipergunakan secara apik. Majas yang sering dipergunakan adalah metafora yaitu membandingakn suatu hal dengan hal lain. Tujuan penggunaan metafora itu untuk memberikan memberikan kejelasan angan, seperti kalimat semabuk-mabuk puisi, Setulus-tulus puisi, serahasia pusi, palung kalbu. Selain itu, penggunaan majas personifikasi terdapat dalam kalimat didekapinya mimpi.

Pemakaian ritme dan rima memperindah puisi ini seperti dalam kalimat hati rentan puji kini diuji. Ritme dalam kalimat ini seolah menggambarkan suasana hati yang mudah naik maupun turun tergantung suasana; naik kala dipuji dan turun kala diuji. Rima dipergunakan pada bait pertama dengan bunyi akhir vokal $[i]$ yang menggambarkan rasa bahagia, ringan, dan ceria. Rima ini terinspirasi dari bentuk syair yang mempunyai sajak sama tiap akhir kalimat.

Dari seluruh aspek keindahan dan penilaian tersebut (diksi, kata nyata, imaji, majas, ritme dan rima) tergambar jelas bagaimana stilistika pada puisi ini. Aspek-aspek dipergunakan secara baik dan benar-benar dimanfaatkan oleh penyair untuk membangun keindahan puisinya secara utuh. 


\section{JURNAL ILMIAH \\ BINA EDUKASI \\ ISSN 1979-8598 E-ISSN: 2655-8378 \\ http://journal.binadarma.ac.id/index.php/jurnalbinaedukasi \\ Vol. 13, No. 1, Juni 2020, 52 - 64}

Nilai-nilai dalam puisi ini pun amat beragam. Para siswa mendapatkan warna baru dalam pembelajaran bahasa dan sastra Indonesia, terutama dalam analisis puisi. Dengan demikian, puisi ini bisa melatih siswa untuk proaktif, responsif dan mengambil berbagai nilai moral yang yang menjadikan siswa berperilaku baik, terutama dalam menghargai kaum perempuan. Dengan demikian, puisi ini dapat dipergunakan sebagai salah satu contoh konkret dalam pembelajaran analisis puisi bagai siswa SMA.

\section{DAFTAR PUSTAKA}

Al Ma'roef. Ali Imran. (2009). Stilistika: Teori, Metode, dan Aplikasi Pengkajian Estetika Bahasa. Solo: CakraBooks.

Fransori, Arinah. (2017). Analisis Stilistika pada Puisi Kepada Peminta-Minta Karya Chairil Anwar". Deiksiss. 9(1), 1-12.

Harjono, Nyoto. (2012). "Kajian Stilistika pada Puisi-Puisi Chairil Anwar Sebagai Sarana Pebelajaran Apresiasi Sastra". Scholaria. 2(1), 22-38. https://repository.uksw.edu/bitstream/123456789/3189/2/pdf. Diunduh pada tanggal 20 Januari 2020.

Kartono, Kartini. (2006). Psikologi Wanita: Mengenal Gadis Remaja dan Wanita Dewasa. Bandung: Mandar maju.

Luxemburg. Jan van. (1992). Pengantar Ilmu Sastra. Jakarta: Gramedia.

Ratna, Nyoman Kutha. (2013). Stilistika. Yogyakarta: Pustaka Pelajar.

Rennuati, Dian. (2018). Perempuan Selalu Ingat. Jakarta: Halaman Moek Publising.

Santoso, Anang. (2009). Bahasa Perempuan: Sebuah Potret Ideologi Perjuangan. Bandung: Bumi Aksara.

Semi, M. Atar. (2012). Metode Penelitian Sastra. Bandung: Angkasa.

Siswanto, Wahyudi. (2013). Pengantar Teori Sastra. Malang: Aditya Media.

Tarigan, Henry Guntur. (2015). Prinsip-Prinsip Dasar Sastra. Bandung: Angkasa.

Yuliantini, Tenti. (2019). "Kajian Stilistika terhadap Diksi dalam Kumpulan Puisi Malu (Aku) Jadi Orang Indonesia Karya Taufiq Ismail serta Pemanfaatannya sebagai Bahan Ajar Bahasa Indonesia di SMK". Wistara: Jurnal Pendidikan Bahasa dan Sastra. 2(1), 36-45, https://journal.unpas.ac.id/index.php/wistara/article/view/2292. Diunduh pada tanggal 05 Februari 2020. 